\title{
ULTRASTRUCTURAL CHANGES IN THE SYNOVIAL MEMBRANE IN LIPOHAEMARTHROSIS
}

\author{
BY
}

\author{
F. N. GHADIALLY AND S. ROY* \\ From the Department of Pathology, University of Saskatchewan, Canada, and the Department of Pathology, \\ University of Sheffield, England
}

Severe trauma to a joint may lead not only to the liberation of blood into the joint cavity from ruptured blood vessels but also of lipid from juxta-articular fat pads and adipose subsynovial tissue when the synovial membrane is torn or from the bone marrow when an intra-articular fracture has occurred. It seems to us that such traumatic incidents leading to lipohaemarthrosis must occur quite frequently, yet the condition has received only scant attention in text books and papers (Collins, 1949; Abrams, 1966; Peirce and Eaglesham, 1942; Senturia and Simon, 1947) and the unique ultrastructural changes that occur have not as yet been described.

During the course of our ultrastructural studies of the synovial membrane from normal and pathological joints, we came upon a case of lipohaemarthrosis. Both clinical and light microscopical studies of routine haematoxylin and eosin stained sections had led to the diagnosis of haemarthrosis. Since the possibility of lipohaemarthrosis was overlooked tissues were not collected for frozen sectioning.

\section{History}

The patient was a male aged 16 years who had injured his left knee in a road traffic accident. $X$-ray examination showed fracture separation of the upper tibial epiphysis, and the fracture line running into the joint (Fig. 1). $250 \mathrm{ml}$. blood were aspirated from the joint space. A fortnight later when the abrasions around the joint had healed the knee was operated upon. It was once more found to be full of blood. Specimens of synovial membrane were collected for study from the infrapatellar region.

\section{Material and Methods}

The synovial tissue obtained as described above was divided into two pieces; one was fixed in formalin and processed for light microscopy and the other was placed on a piece of filter paper and dropped in buffered cold

* Present address: Department of Pathology, All India Institute of Medical Sciences, Medical Enclave, New Delhi 16, India.

Address for reprints: Dr. F. N. Ghadially, Department of Pathology, University of Saskatchewan, Canada. osmium (Palade, 1952). After fixation for $2 \mathrm{hrs}$ at $4^{\circ} \mathrm{C}$ the tissue was cut into thin strips about $1 \mathrm{~mm}$. wide The synovial membrane with a minimum of subsynovia tissue was dissected off the filter paper leaving behind most of the collagenous and fatty tissue which would have interfered with the cutting of ultrathin sections. The synovial tissue was then processed by the method of Glauert (1961) and orientated according to the method of Coulter (1962). Ultrathin sections were cut with the Porter Blum microtone, mounted on uncoated copper grids, stained with lead citrate (Reynolds, 1963), and examined under the A.E.I. E.M.6, using an accelerating voltage of 50 or $75 \mathrm{kV}$. Half $\mu$ thick sections were also cut from the araldite blocks. These were stained with hot metachromatic blue (1 per cent.) and examined

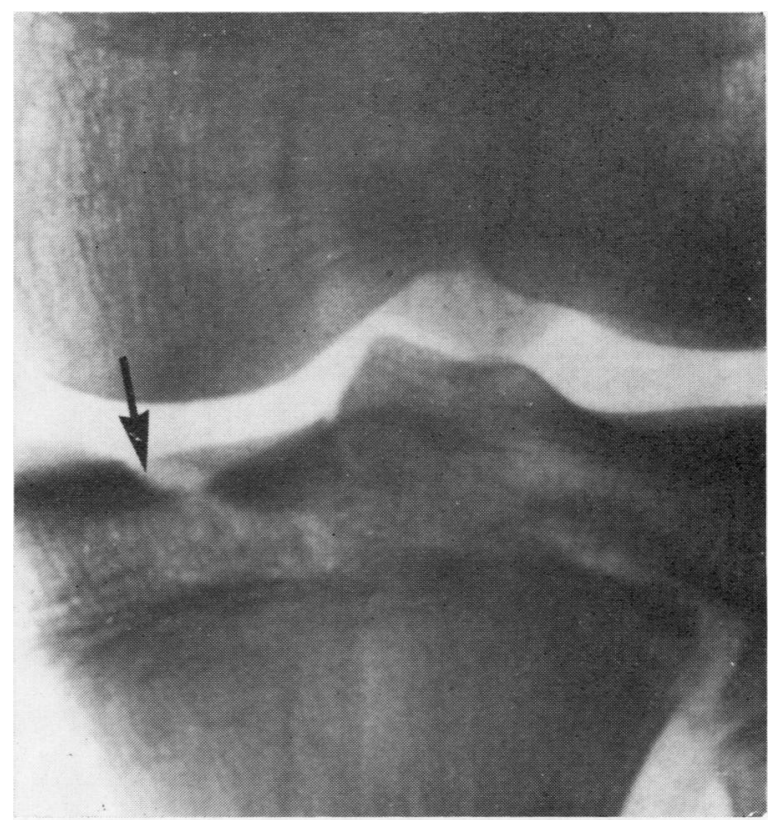

Fig. 1.-Roentgenogram of left knee, showing fracture of upper tibial epiphysis (arrow). 
under the light microscope. From the synovial membrane processed for light microscopy, paraffin sections were cut and stained with haematoxylin and eosin, Perl's Prussian blue reaction for iron, Alcian blue (pH 2.6), the modification of McManus and Mowry (1960) of Hale's colloidal iron for acid mucopolysaccharides, and methyl green-pyronin for ribonucleic acid.

\section{Light Microscopy}

\section{Results}

There was a patchy proliferation of synovial intimal cells, and also some focal villous formation. In some areas the synovial cells were rather large and showed an abundant foamy cytoplasm (Fig. 2). This foaminess was probably due to the presence of lipid. A number of erythrocytes were found lying freely in the matrix and subsynovial tissue. Many focal, usually perivascular, aggregates of inflammatory cells and some fibrosis were detected in this region. A positive reaction for iron was obtained by the Prussian blue method both in the synovial intimal cells and subsynovial macrophages. Methyl green-pyronin stain for ribonucleic acid demonstrated a more intense staining reaction and an increase in the number of RNA positive synovial intimal cells. Alcian blue and colloidal iron stain for acid mucopolysaccharides yielded a stronger positive reaction in the subsynovial tissue than was found in the normal state.

\section{Ultrastructural Findings \\ A. Synovial Cells}

Electron microscopy confirmed the focal proliferation of cells seen by light microscopy and showed that this was due mainly to an increase in the number of intermediate and Type B cells (Fig. 3). Abundant rough endoplasmic reticulum, often showing moderate or marked dilatation of the cisternae, was present in many synovial cells. The formation of desmosomes and tight junctions was not detected nor were any overt changes observed in the matrix. Filopodia were well developed and they were seen more frequently than in the normal. Many micropinocytotic vesicles were also frequently encountered. In most cells the mitochondria appeared fairly normal, but at times swollen mitochondria with distorted cristae were also seen.

Lipid.-Indubitably the most interesting change witnessed in this case was the remarkable increase in lipid seen in many but not all synovial cells. At times the synovial cells were packed with large

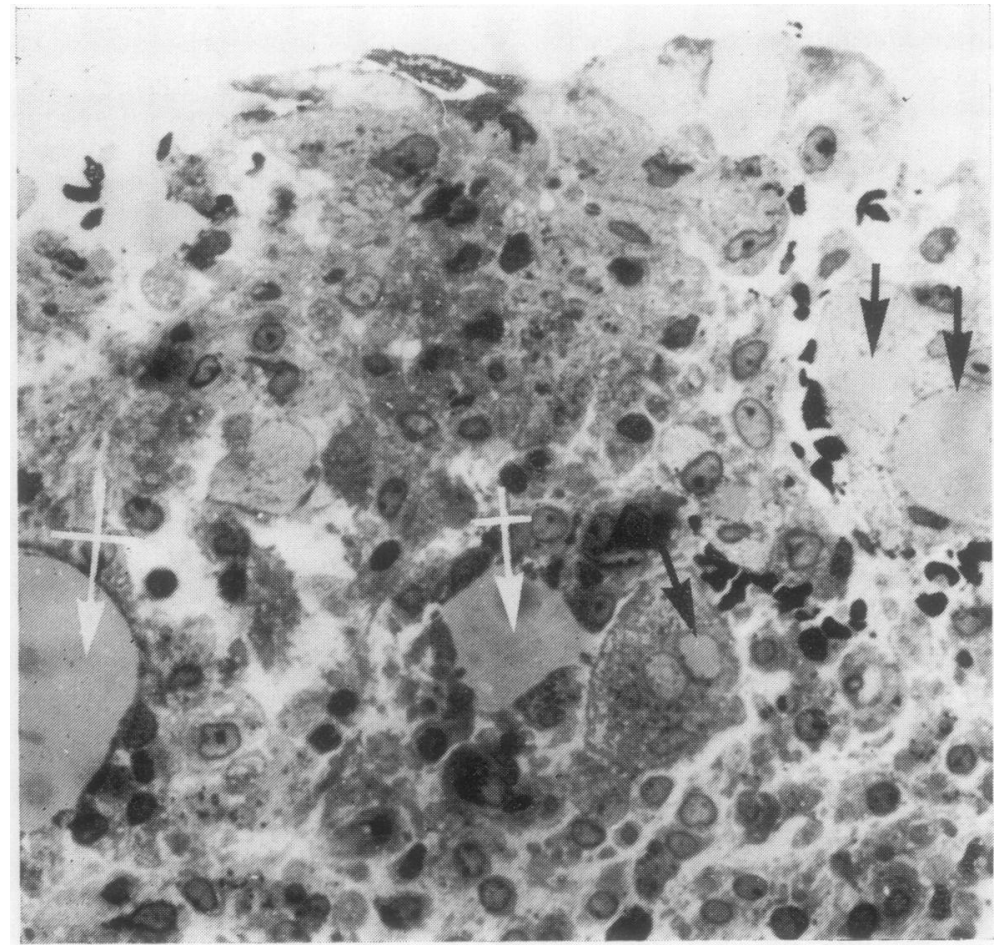

Fig. 2.-Light microscopical appearance of section from araldite block, stained with metachromatic blue. Many synovial cells contain pale foamy cytoplasm. Larger lipid droplets of variable size occur within synovial cells (arrow) and also outside them (crossed arrow). Many erythrocytes are lying free in the matrix. $\times 330$. 


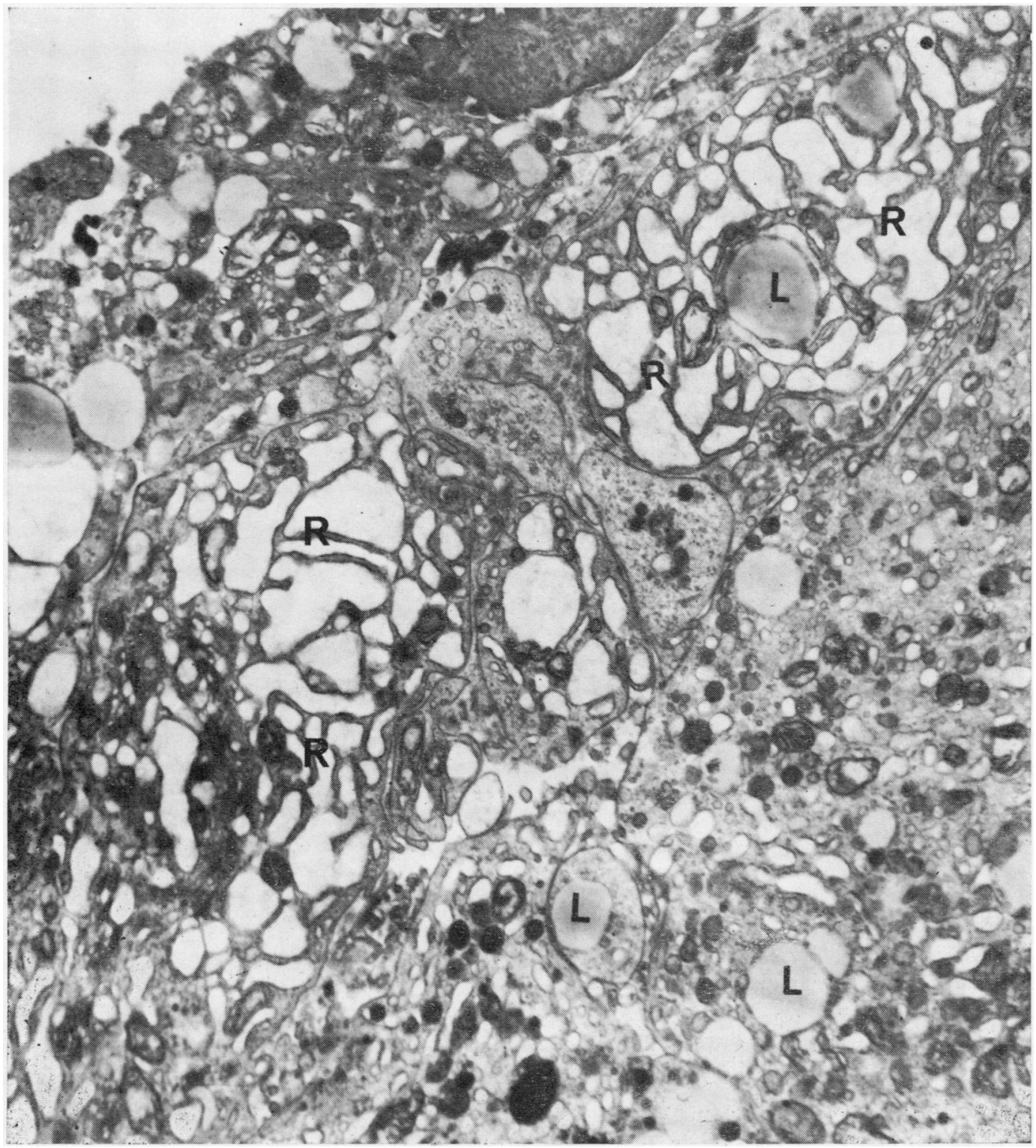

Fig. 3.-Low-power electron micrograph, showing abundant rough endoplasmic reticulum (R) in synovial cells. Many low density lipid droplets $(L)$ are also seen. $\times 9,500$.

numbers of lipid droplets. In electron micrographs such lipidic deposits appeared in various forms:

(1) Numerous electron lucent areas (Fig. 4, overleaf) which either contained electron lucent lipid or in which the lipid had dissolved away during preparation of the specimen.
(2) Large collections of low density droplets (Fig. 5, overleaf).

(3) Small collections of medium density droplets frequently surrounded by and/or peppered with electron dense granules (Fig. 6, overleaf). (This is similar to the type of lipid most frequently seen in the normal synovium). 


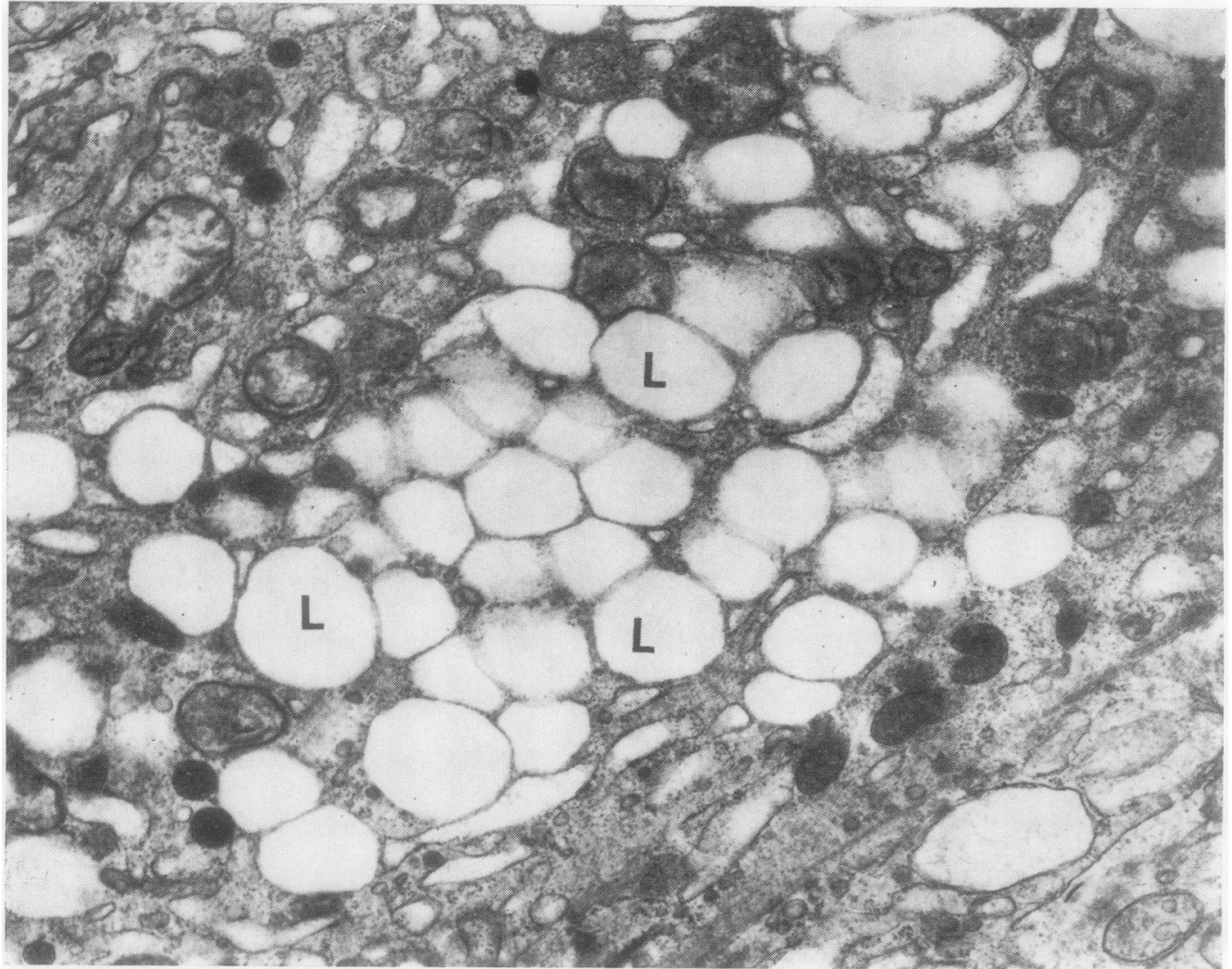

Fig. 4.-Synovial cell, showing numerous electron lucent areas (L), containing either electron lucent lipid or lipid which has dissolved away during preparation of the specimen. $\times 20,000$.

(4) Very occasionally a few high density or electron opaque droplets were also seen.

The large majority of lipid deposits seen in lipohaemarthrosis were similar to those described under 1 and 2. There was also, however, a clear-cut increase in the "normal-looking" lipid similar to that described under 3. Very rarely lipid droplets were also seen in the nucleus (Fig. 7).

Fine filamentous fibres.-No increase was detectable. Thus the situation seen here resembles that seen in acute haemarthrosis where no increase in fine filamentous fibres is known to occur rather than that seen in chronic haemarthrosis where there is such an increase.

Erythrophagosomes.-Bodies containing recognizable erythrocyte fragments and bodies containing whorled electron dense membranes similar to those reported by us previously (Roy and Ghadially, 1966; 1967) were occasionally encountered.

Siderosomes.-Numerous siderosomes were encountered in the synovial cells. These single membrane-bound lysosomal bodies containing electron dense iron particles were similar to those found in haemarthrosis (Roy and Ghadially, 1967, 1969).

Electron dense particles containing iron.-In traumatic and experimental haemarthrosis electron dense particles measuring approx. 50-70 $\AA$ in diameter are sometimes seen scattered in the cytoplasm of synovial cells. Such particles were also found in a few synovial cells in this case.

\section{B. Subsynovial Tissue}

Electron microscopy confirmed the light microscopical findings of many inflammatory cells in the 


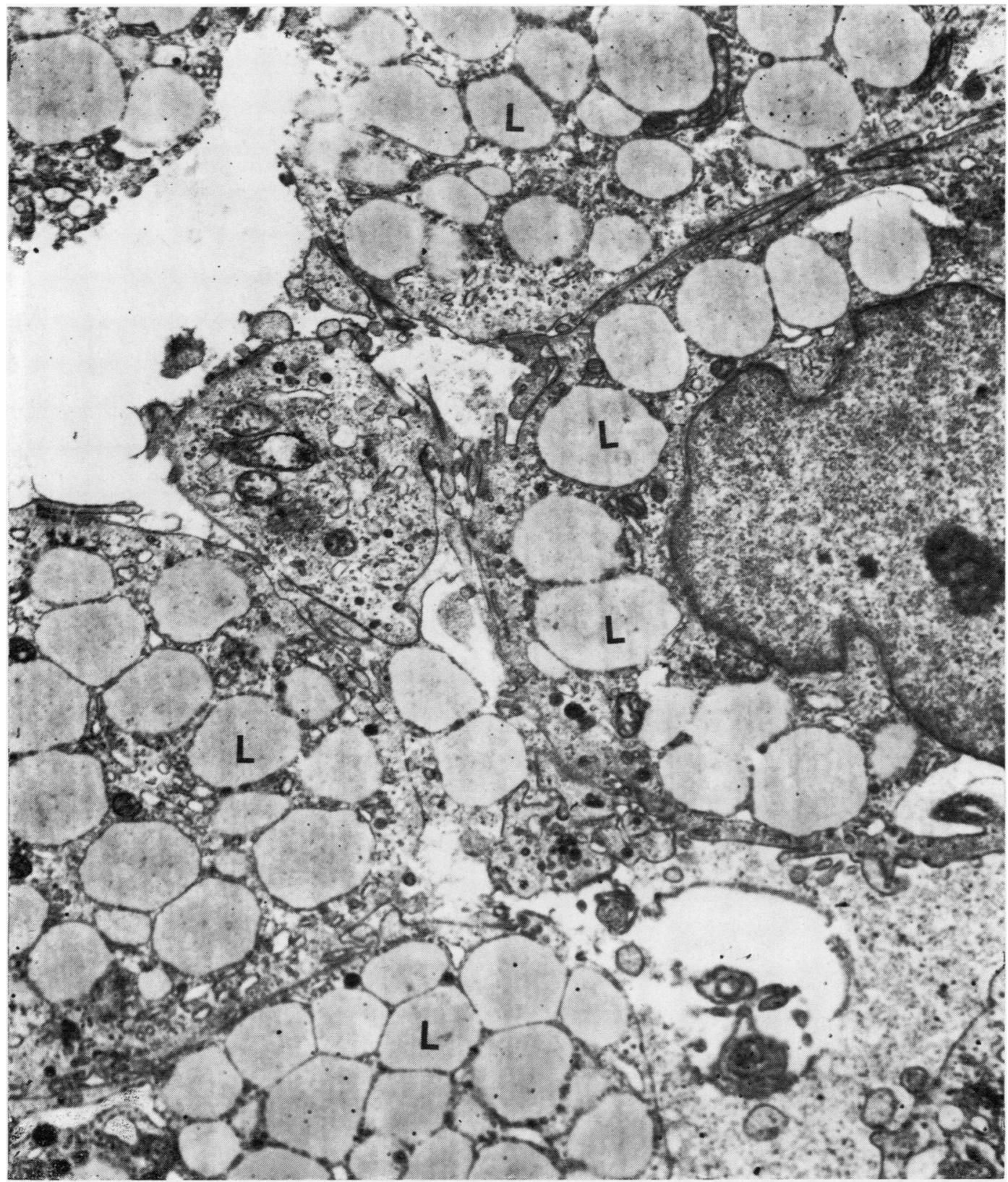

Fig. 5.-Group of synovial cells containing numerous lipid droplets (L) of low electron density. $\quad \times 10,000$.

subsynovial tissue. These cells were mostly lymphocytes and macrophages. Some of the latter, especially those in the superficial subsynovial region, contained large number of fat droplets. Many fibroblasts and blood vessels were also encountered.

\section{Discussion}

The significance of many of the changes seen in this case have been discussed in our previous papers and need only brief mention here. 


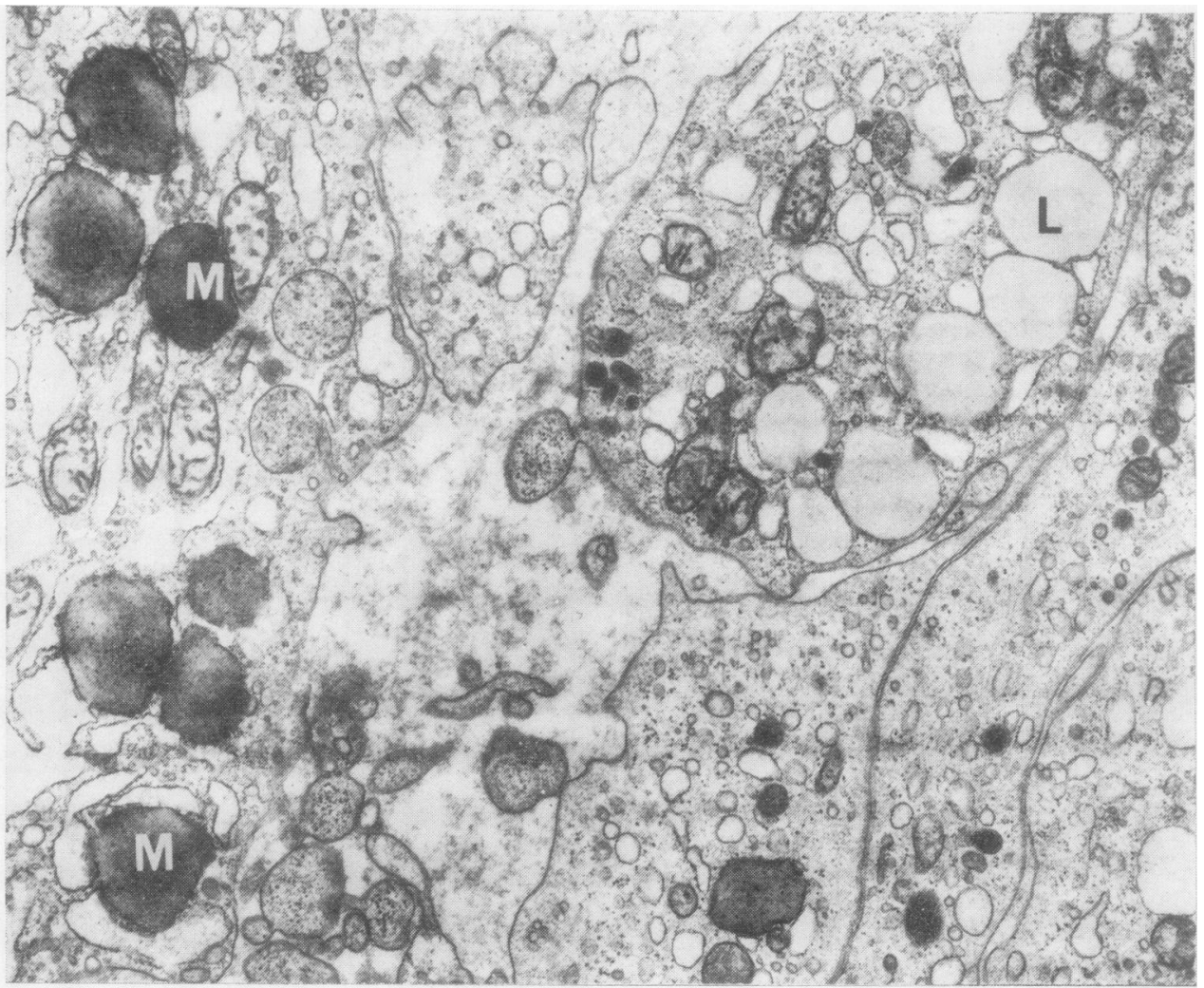

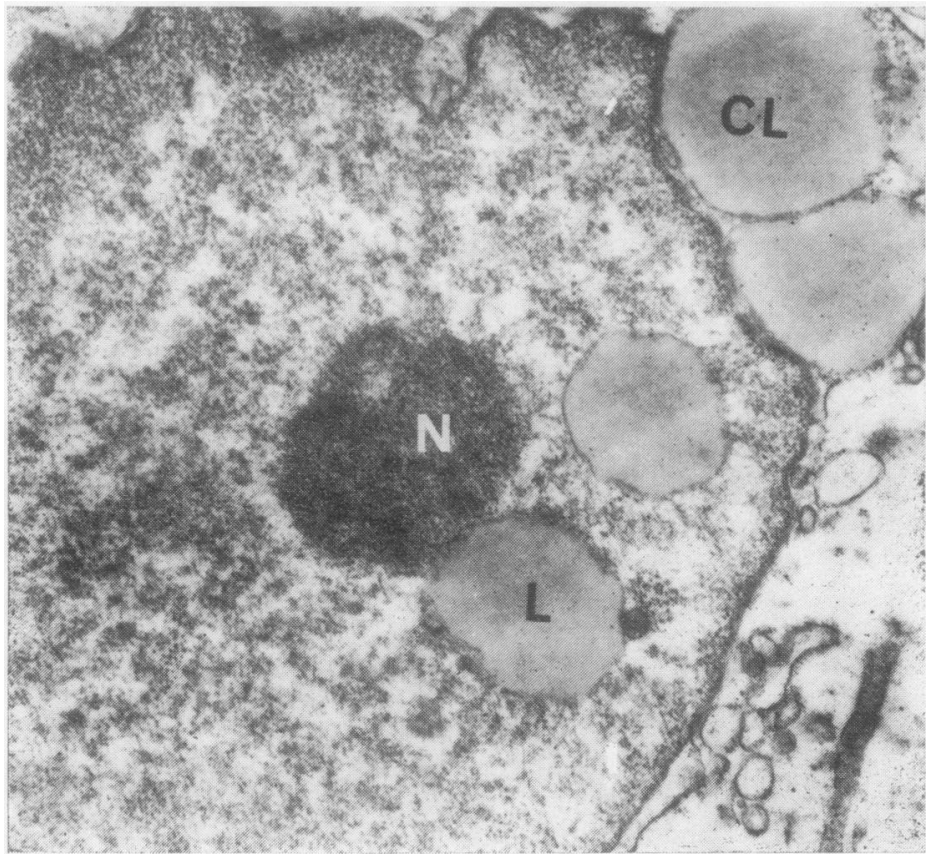

Fig. 6.-Synovial cells containing lipid droplets of both low (L) and medium (M) density. $\times 14,000$.

Fig. 7.- Synovial cells, showing intranuclear (L) and intracytoplasmic (CL) lipid droplets of low density. Nucleolus $(\mathrm{N}) . \quad \times 27,500$. 


\section{Rough Endoplasmic Reticulum}

An increase in the population of intermediate and Type B cells, with the increase in the amount of rough endoplasmic reticulum which this entails, is a common feature in a variety of pathological states of the synovium (Roy, Ghadially, and Crane, 1966; Roy and Ghadially, 1967; Ghadially and Roy, 1967; Wyllie, Haust, and More, 1966; Roy, 1967). Light microscopically this change is reflected by the heightened staining reaction noted with the methyl green-pyronin method. A modest degree of cisternal dilatation frequently accompanies this increase in rough endoplasmic reticulum and probably reflects the heightened protein synthetic activity going on within the cell. However, it seems to us that gross dilation of the cisternae in most instances indicates cellular degeneration. This is supported by the fact that in such cells there is a paucity of other organelles or pathological changes in them.

\section{Increase in Lipid}

The finding of a lipid droplet in the synovial cell in a section of normal synovial membrane is a fairly rare event. In many pathological states a modest increase in lipid occurs, so that quite a few cells show a lipid droplet, and occasionally small collections of droplets are seen in a single cell. Such lipid is usually of medium density and likely to be peppered and/or surrounded by electron dense granules.

In lipohaemarthrosis, however, collections of innumerable lipid droplets of a different kind also occur in synovial cells. Such droplets are represented as electron lucent areas or as areas of low density in electron micrographs. A plausible explanation of this phenomenon would be that since in lipohaemarthrosis the lipid is derived from adipose tissue it consists mainly of tri-glycerides of fatty acids - probably saturated fatty acids - which would not be fixed by osmium, and would hence be removed by the agents used for dehydrating and embedding the tissue. In the case of the low-density droplets one might assume that, although the lipid is not very osmophilic, it is sufficiently fixed to resist removal by solvents. This may be due to the presence of some unsaturated fatty acids or admixture with some other osmophilic lipid.

The notion that these differences in staining densities are produced by variations in fixing and staining techniques cannot be entertained in this instance, for the different forms of lipids may be found in the same ultra thin section and at times even within a single cell (Fig. 6). There is little doubt, therefore, that these differences represented chemical differences in the lipid droplets.

Our studies of this case have not indicated the mechanism by which lipid shed into the joint space enters the synovial cells. It would be interesting to study the manner in which various lipids are removed after injection into the joints of experimental animals, for this would not only indicate whether this is accomplished via micropinocytotic vesicles, phagocytosis, or other means but also permit a correlation to be made between the chemistry of the lipid and electron density of lipid droplets seen in electron micrographs.

\section{Siderosomes and Electron Dense Iron-containing Particles}

These bodies and particles have been observed by us in synovial cells and subsynovial macrophages from the synovial membrane of haemarthrotic joints (Roy and Ghadially, 1966, 1967; Roy and Ghadially, 1969). They are ultimately derived from the haemoglobin of the shed blood. The nature and significance of these structures have already been discussed in previous papers and hence no further comment is necessary here.

\section{Summary}

Many of the ultrastructural changes that occur in the synovial membrane in lipohaemarthrosis are also found in haemarthrosis. Such changes include an increase in intermediate and type B cells, and the occurrence of siderosomes, and iron-containing electron dense particles scattered freely in the cytoplasm of synovial cells and subsynovial macrophages. The characteristic change is the accumulation of large numbers of lipid droplets within some synovial cells and subsynovial macrophages. Lipid droplets of various electron density were observed. Since these density variations occurred even within a single section, this was not a preparation artefact but reflected differences in chemical composition of the lipid.

This work was supported by the Arthritis and Rheumatism Council. We are grateful to Mr. T. E. Durrant and Miss Marion Maynard for technical assistance. 


\section{REFERENCES}

Abrams, N. R. (1966). "Traumatic arthritis and allied conditions", in "Arthritis and Allied Conditions. A Textbook of Rheumatology", ed. J. L. Hollander, 7th ed., p. 1151. Lea and Febiger, Philadelphia.

Collins, D. H. (1949). "The Pathology of Articular and Spinal Diseases". Arnold, London.

Coulter, W. H. (1962). Arthr. and Rheum., 5, 70 (The characteristics of human synovial membrane as seen with the electron microscope).

Ghadially, F. N., and Roy, S. (1967). Ann. rheum. Dis., 26, 426 (Ultrastructure of synovial membrane in rheumatoid arthritis).

Glauert, A. M. (1961). In "Technique for Electron Microscopy", ed. D. Kay, pp. 179-181. Blackwell, Oxford.

McManus, J. F. A., and Mowry, R. W. (1960). " "Staining Methods: Histologic and Histochemical", p. 135. Hoeber, New York.

Palade, G. E. (1952). J. exp. Med., 95, 285 (A study of fixation for electron microscopy).

Peirce, C. B., and Eaglesham, D. C. (1942). Radiology, 39, 655

Reynolds, E. S. (1963). J. Cell Biol., 17, 208 (The use of lead citrate at high pH as an electron-opaque stain in electron microscopy).

Roy, S. (1967). Ann. rheum. Dis., 26, 517 (Ultrastructure of synovial membrane in osteo-arthritis).

and Ghadially, F. N. (1966). Ibid., 25, 402 (Pathology of experimental haemarthrosis).

- (1967). J. Bone Jt Surg., 49-A, 1636 (Ultrastructure of synovial membrane in human hemarthrosis).

- - (1969). Ann. rheum. Dis., 28, 402 (Synovial membrane in experimentally-produced chronic haemarthrosis).

,-- , and Crane, W. A. J. (1966). Ibid., 25, 259 (Synovial membrane in traumatic effusion. Ultrastructure and autoradiography with tritiated leucine).

Senturia, H. R., and Simon, H. E. (1947). Amer. J. Surg., 73, 79 (Traumatic lipohemarthrosis. Layering of fat and blood in a joint).

Wyllie, J. C., Haust, M. D., and More, R. H. (1966). Lab. Invest., 15, 519 (The fine structure of synovial lining cells in rheumatoid arthritis).

Les changements ultrastructurels de la membrane synoviale dans la lipohémarthrose

\section{RÉSUMÉ}

Beaucoup de changements ultrastructurels de la membrane synoviale qui ont lieu dans la lipohémarthrose sont aussi trouvés dans l'hémarthrose. De tels changements comprennent aussi une augmentation des cellules du type intermédiare et du type $\mathrm{B}$, la présence des sidérosomes et des particules contenant du fer denses au microscope électronique répandues librement dans le cytoplasme des cellules synoviales et des macrophages sous-synoviaux. Le changement caractéristique est l'accumulation d'un grand nombre de gouttelettes lipides dans certaines cellules synoviales et certains macrophages sous-synoviaux. Des gouttelettes lipides de densités variées au microscope électronique ont éte observées. Du fait que ces variantes de densités ont lieu dans une même coupe, il n'est pas question d'une erreur due à la préparation mais elles reflétaient les différences dans la composition chimique du lipide.
Cambios ultraestructurales en la membrana sinovial en la lipohemartrosis

\section{SUMARIO}

Muchos de los cambios ultraestructurales que ocurren en la membrana sinovial en la lipohemartrosis se encuentran también en la hemartrosis. Esos cambios abarcan un aumento de las células intermedias y tipo B, y la presencia de siderosomas y de partículas densas de electrones de hierro, diseminadas en abundancia en el citoplasma de células sinoviales y macrófagos subsinoviales. El cambio característico radica en la acumulación de gran numero de gottias lípidas dentro de algunas células sinoviales y macrófagos subsinoviales. Se observaron gotitas lípidas de varias densidades electrónicas. Estas variaciones de densidad ocurrían aun dentro de una sola sección, pues no se trata agui de un artefacto, sino de diferencias en la composición química del lípido. 